\title{
Retail Sales of Durable Goods, Inventories and Imports after Large Devaluations
}

\author{
Valery Charnavoki *
}

February, 2017

\begin{abstract}
This paper presents a general equilibrium model of a small open economy with monopolistically competitive retailers, inventories and durable goods. Following large devaluations, this model generates a collapse of imports, a fall of retail sales and inventories and a gradual increase in retail prices. Besides, the model allows to explain a short-lived spike in retail sales of durable goods, observed during the recent devaluation episode in Russia in December of 2014.
\end{abstract}

KEYWORDS: durable goods, inventories, retail sales, small open economy

JEL Classification: D92, E21, F41, F44, L81

*New Economic School, 100A Novaya Street, Skolkovo, Moscow, Russia, 143026 (e-mail: vcharnavoki@ nes.ru) 
... On his way home from work tonight, with the near-collapse of Russia's currency on his mind, Maxim Legonkikh made something of an impulse buy. He pulled into the Porsche dealership and bought himself a brand new sports car. In cash. "It's an incredible deal," he explained. "I'm only here because I need to find a safe place for my money." (by Kirit Radia, $A B C$ News, $16 / 12 / 2014)$

\section{Introduction}

On Monday, December 15th of 2014, after rumours were spread that the Russian oil giant, Rosneft, borrowed $625 \mathrm{bn}$ roubles $(\$ 9.9 \mathrm{bn})$ in an opaque deal, involving the central bank, Russian currency went into free-fall. During this day rouble dropped over 10 percent. A middle-of-the-night increase in policy rate from 10.5 to 17 percent by the Bank of Russia failed to reverse this fall, and to 3pm on "Black Tuesday" rouble lost additional 23 percent of its value. In the following days, Russians flooded stores and shopping malls in an attempt to spend their shrinking in worth roubles on durable (mostly imported) goods. Diamonds and sports cars, smartphones, fridges and TVs were selling like hot cakes. As a result of this shopping frenzy, the sales of non-food goods rose in December by $11.5 \%$ on the year-over-year basis, whereas food sales hardly changed. However, the shopping spree was over as quickly as it began. Retailers had sold out their inventories and were being forced to adjust their prices following the rising prices of import. The following months were marked by a sharp fall of imports and retail sales and rising inflation.

In this paper, I propose a general equilibrium model of a small open economy with imported durable goods, monopolistically competitive retailers and inventories and show that quantitative predictions of this model are in line with the stylized facts about the effects of large devaluations on retail sales, imports, inventories and consumer prices. In particular, similarly to Alessandria, Kaboski, and Midrigan (2010), this model generates a fall of imports, retail sales and inventories, and a gradual rise of consumer prices. Moreover, a slight modification of this model based on predetermined retail prices allows to explain a temporary spike in retail sales of durable goods observed in Russia in December of $2014 .^{1}$

There are two basic approaches in the literature which explain the role of inventories in retail trade: the fixed ordering costs theory and the stock-out avoidance theory. ${ }^{2}$ The first approach, pioneered by Scarf (1960), is based on the fixed ordering costs which

\footnotetext{
${ }^{1} \mathrm{~A}$ similar short-lived spike in retail sales of durable goods occurred in Belarus after large devaluation of Belarusian rouble in April-May, 2011.

${ }^{2}$ There is the third approach, the production-smoothing theory, which was designed to explain the manufacturers' inventories of finished goods. However, as stressed by Blinder, Lovell, and Summers (1981), this approach is not generally applicable to retailers' inventories, since the typical retailer unlikely faces rising marginal costs of purchasing, necessary for this theory.
} 
generate infrequent and lumpy orders and (S,s)-behaviour of inventories. Aguirregabiria (1999) combines this theory of inventories with menu costs of adjusting retail prices to explain the existence of sales promotions. Alessandria et al. (2010) use joint (S,s)-model of inventories and price changes to demonstrate a short-term collapse of imports and a gradual increase in the retail prices of import goods after large devaluations.

The second method, the stock-out avoidance theory (see Kahn, 1987; Wen, 2005, among others), assumes that retailers place their orders and build up inventories before learning their demand shocks. As a result, to avoid losses related to stock-outs, they have an incentive to build up excess (precautionary) inventories. In contrast to the fixed ordering costs theory, the models with the stock-out avoidance motive are linearizable and may be easily incorporated into the framework of general equilibrium business cycle models. In particular, Kryvtsov and Midrigan (2013), propose a New Keynesian model with stock-out avoidance motive for holding inventories and analyse how markups, costs and inventories vary in response to monetary policy shocks. Alessandria, Kaboski, and Midrigan (2013) introduce an inventory management problem into a two-country model of international business cycles and re-examine the role of international trade in propagating business cycles.

In this paper, I follow the second approach and incorporate a stock-out avoidance motive into the business cycle model of a small open economy (similar to Mendoza, 1991; Schmitt-Grohe and Uribe, 2003). As in Alessandria et al. (2013), I assume that idiosyncratic demand shocks of retailers are Pareto distributed, which simplifies computation of equilibrium conditions. However, I use slightly different timing assumptions for the inventory and price decisions of the retail firms. First, the retailers are required to place their import orders and build up inventory stocks before learning aggregate demand shocks. ${ }^{3}$ This allows to rationalize a backlog of inventories emerging after negative aggregate demand shocks, such as large devaluations, and explain a collapse in import after these events.

Second, in regard to pricing decisions, I consider two variants of the model. In the first one, the retailers choose their prices after the overall (aggregate and idiosyncratic) uncertainty in the current period is resolved. After large devaluation shock, this model replicates a collapse of imports, a fall of inventories and retail sales as well as an increase in the retail prices. However, under a reasonable parametrization, it fails to explain a temporary spike in retail sales of durable goods observed in December, 2014. In this model, the retailers quickly adjust their prices to higher import costs, so the consumers have no incentive to shift their future purchases of durable goods for today in an expectation of the future increase in retail prices.

To solve this problem, in the second version of the model, I assume that the retail prices

\footnotetext{
${ }^{3}$ In Alessandria et al. (2013) and Kryvtsov and Midrigan (2013) the orders are placed after aggregate uncertainty in the current period is resolved.
} 
are preset before the retailers observe aggregate and idiosyncratic shocks. However, given that inventories are also chosen in advance, some of the retailers will experience shortages in the next period. To avoid rationing by these firms, I allow them to reset their prices upwards to the levels eliminating exactly the shortages. As a result, this modified version of the model succeeds to generate a short-term spike in the retail sales of durable goods, which cannot be replicated for non-storable non-durable goods.

This rest of the paper is organized as follows. Section 2 discusses the effects of large devaluations on retail sales, inventories, imports and consumer prices using an evidence from two devaluation episodes in Russia, in 2008 and 2014. Section 3 presents the main features of the benchmark model, discusses its calibration and reports its simulations results. Section 4 provides an analysis of the model with predetermined prices. Section 5 discusses sensitivity checks. Finally, Section 6 concludes.

\section{Data: evidence from Russia}

In this section, I use Russian data to document several basic facts about the effects of large devaluations on retail sales, inventories and prices of imported goods, as well as differences in these effects for durable and non-durable goods. The data are taken from the Federal State Statistics Service (Rosstat) database and cover the period from 2005 to $2015 .^{4}$

The top-left panel of Figure 1 illustrates the dynamics of the nominal exchange rate of Russian rouble to US dollar in 2005-2015. It is clear, that during this period Russia experienced two major devaluation episodes: in 2008 and in 2014. Both events were associated with a strong fall in price of crude oil, which constitutes a significant share of Russian export. ${ }^{5}$ In 2008, oil prices started to fall in July after President Bush lifted a ban on offshore drilling in the United States. The collapse of Lehman Brothers in September of 2008 accelerated this fall and triggered capital flight from emerging markets. To combat losses in foreign exchange reserves, Bank of Russia adopted the policy of gradual devaluation. As a result, Russian rouble fell by $50 \%$, from 24 RUB/USD in August 2008 to 36 RUB/USD in February 2009. The events unfolded slightly differently in 2014. During this year rouble was allowed to float freely. Following plummeting oil prices it depreciated from 34 RUB/USD in July to 57 RUB/USD on 14th of December. In the following two days of turmoil in the foreign exchange market rouble fell by $38 \%$ to 79 RUB/USD, despite massive forex interventions by the central bank and a sharp increase of policy rate from $10.5 \%$ to $17 \%$.

\footnotetext{
${ }^{4}$ http://www.gks.ru/

${ }^{5}$ The co-movement between commodity prices and exchange rates in commodity-exporting countries is well documented in the literature (see, for example, Chen and Rogoff, 2003; Cashin, Cespedes, and Sahay, 2004).
} 
The mid-left panel of Figure 1 demonstrates, that after both devaluations the rouble prices of imported goods rose significantly. This fact is easy to explain: most of Russian imports are priced in foreign currency (dollar and euro), and, as demonstrated by Gopinath, Itskhoki, and Rigobon (2010), pass-through of the nominal exchange rate changes to import prices in national currency is high for goods priced in foreign currency. ${ }^{6}$ Moreover, this substantial co-movement between import prices and the nominal exchange rate is in line with findings of Burstein, Eichenbaum, and Rebelo (2005) for other emerging markets (Brazil, Argentina, Korea, Mexico and Thailand).

Figure 1: Large devaluations in Russia: 2008 and 2014
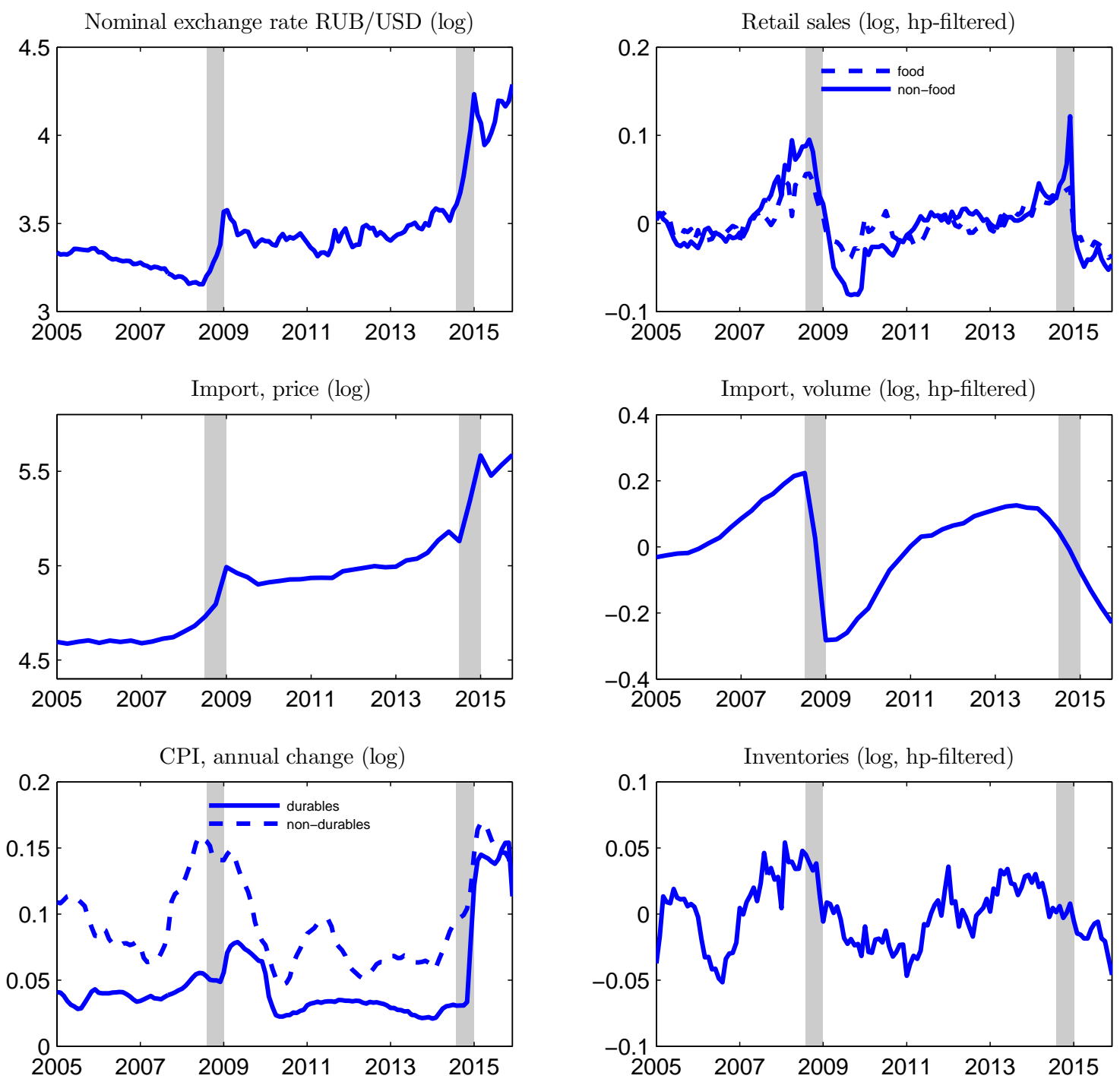

Source: Rosstat database, Bank of Russia.

Rising import prices led to increase in consumer prices of goods (see the bottomleft panel of Figure 1). This increase is especially clear for the prices of durable goods.

\footnotetext{
${ }^{6}$ According to data from the Bank of Russia, 70 percent of imports in 2014 were priced in foreign currency: of them 40 percent in dollars and 28 percent in euros.
} 
However, in contrast to import prices, consumer prices reacted more gradually (again in line with findings of Burstein et al., 2005). Figure 2 demonstrates the dynamics of retail sales and consumer prices for selected durable and non-durable goods around December of 2014, before and after the most acute phase of the currency crisis in 2014. Though the prices of durable goods started to increase in December, when many retailers were being forced to raise them in response to shopping frenzy, the main effect was observed in the following two months. As for non-durable goods, their consumer prices started to rise only in January of 2015.

Figure 2: Retail sales and consumer prices of durables and non-durables in 2014-2015
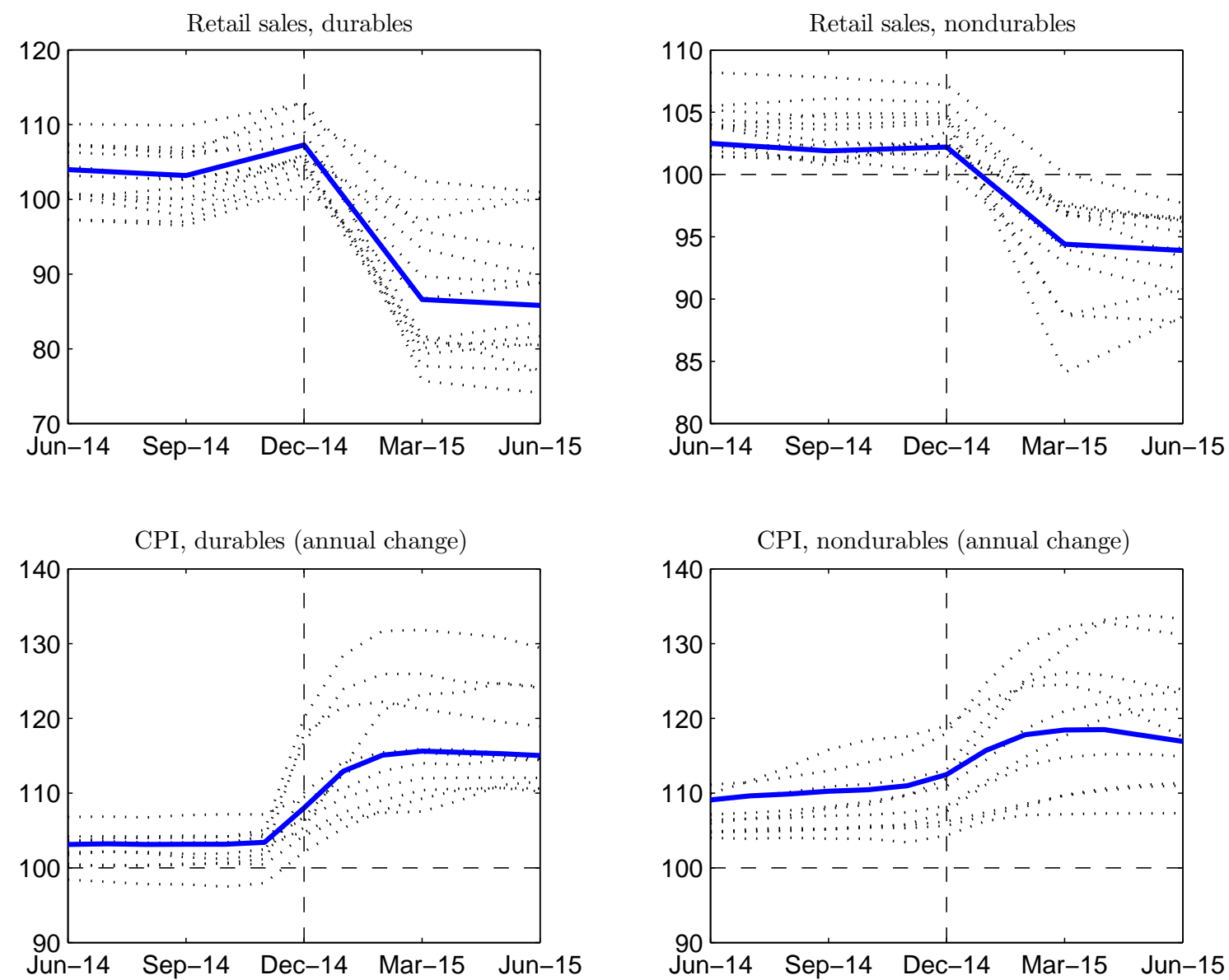

Source: Rosstat database.

Note: Year-over-year ratios. The blue solid lines correspond to averages, the dotted lines depict selected categories of goods. Durables include cars, car parts, furniture, fridges, washers, audio equipment, TV sets, building materials, computers, cameras, mobile phones, watches and jewellery. Non-durables include fruits, vegetables, meat, fish, confectionery, bakery, beverages, milk products, tee, coffee, medicines, cosmetics, outwear, footwear.

The right panels of Figure 1 demonstrate the dynamics of HP-filtered series of the retail sales of food and non-food goods, import volumes and retail inventory stocks. As clearly seen from this figure, all these macroeconomic variables show a decline in the 
months after devaluations in 2008 and 2014. However, the magnitude and duration of this collapse differ across these variables and events. Import declines stronger than retail sales and inventories, especially in 2008. Retail sales of non-food goods, which include durables, are more volatile than retail sales of food. Besides, in December 2014, retail sales of non-food goods demonstrate a clear spike, explained by a shopping frenzy after the collapse of rouble in the mid of this period.

Figure 2 illustrates this episode in more details. It shows the year-over-year growth rates of the retail sales and CPIs of selected durables (cars, TVs, fridges, etc.) and nondurables (foods, clothing, footwear, etc.) before and after the devaluation in December, 2014. It is clear, that retail sales of durables experienced a short-lived increase in December preceding the collapse of the following months. This increase is hardly observed for non-durable goods. Besides, the retail firms selling durable goods started to raise their prices earlier than retail sellers of non-durables.

Figure 3: Retail sales, imports, inventories and consumer prices of selected durables in 2014-2015
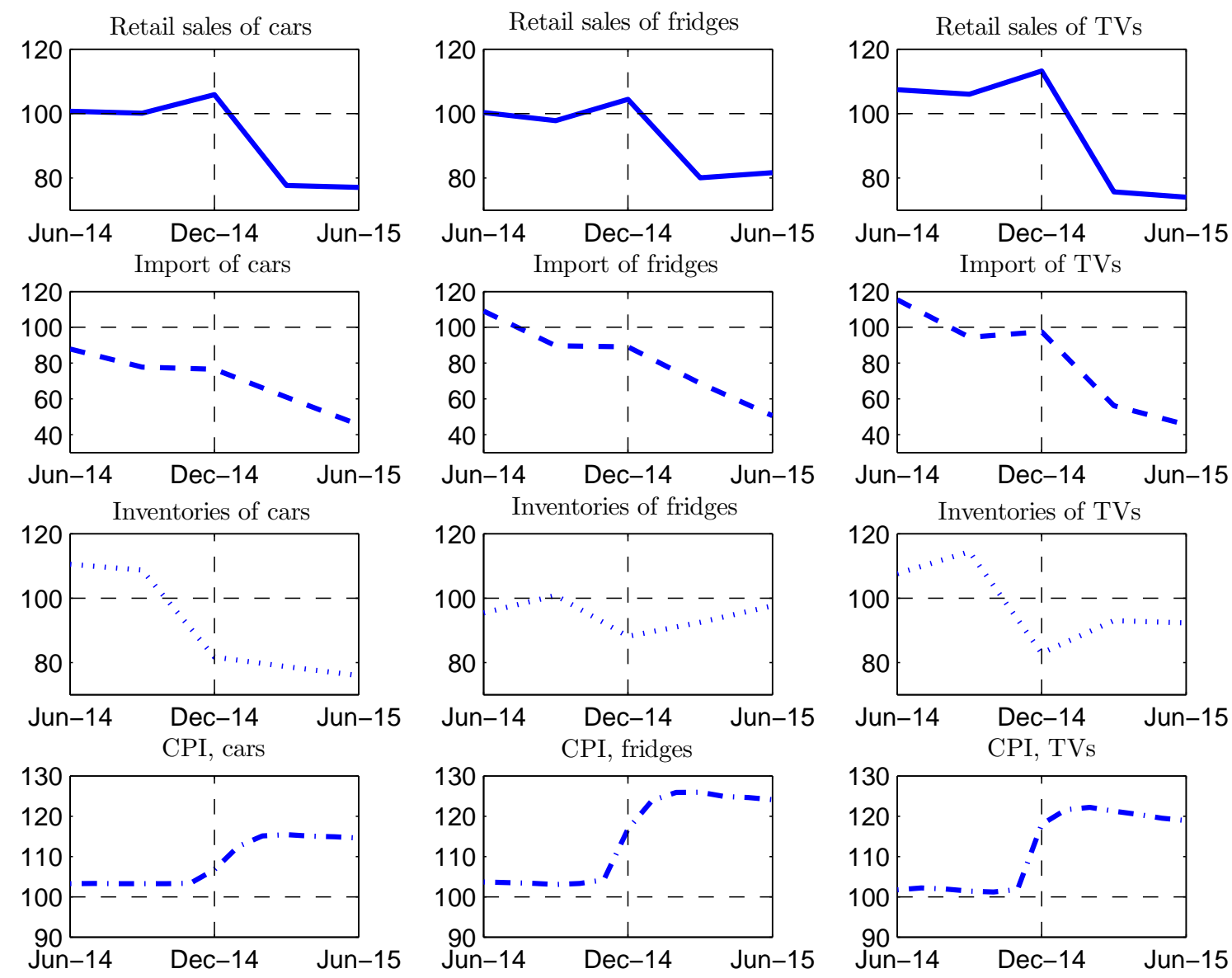

Source: Rosstat database. Note: Year-over-year ratios.

Finally, Figure 3 demonstrates the aforementioned facts for three selected durable goods: cars, fridges and TVs. Besides a gradual increase in retail prices, a collapse of 
imports, short-term spike and the following fall in retail sales, it shows a decrease in end-of-the-period inventories in December, illustrating a higher-than-expected demand on these goods during this month.

\section{Model}

This section presents a general equilibrium model of a small open economy (see, for example, Mendoza, 1991; Schmitt-Grohe and Uribe, 2003), which incorporates a monopolistically competitive retail sector holding inventories of imported durable good. Following Alessandria et al. (2013), inventories are introduced through the assumptions that import orders are placed before uncertainty about retailers demand is resolved and that unsold stocks can be stored with a cost. This creates a stock-out avoidance motive for holding inventories. However, in contrast to Alessandria et al. (2013), I assume that retailers build up their inventory stocks before aggregate shocks are realized, motivating a backlog of inventories in the periods of low aggregate demand.

\subsection{General description of the model}

Consider a small open economy which takes as given the price of imported durable good, $q$, the foreign demand on export good, $x$, and the foreign risk-free interest rate, $r$. In each period $t$, the economy experiences one of the aggregate states $\eta_{t}$. The history of aggregate shocks up to date $t$ is given by $\eta^{t}=\left(\eta_{0}, \eta_{1}, \ldots, \eta_{t}\right)$.

This economy is populated by representative household which consumes the varieties of imported durable good supplied by monopolistically competitive retailers, and can trade internationally risk-free bonds. The household is endowed with a fixed amount of export good and owns all retail firms. There is no labour in this model. So, the household's income is formed by the export proceeds and the profits of retailers.

The retailers buy homogeneous imported good and repack it into varieties of durable good. Each retailer $j$ is faced with idiosyncratic demand shocks $v_{t}^{j}$, which are iid across $j$ and $t$.

The timing in the model is illustrated by Figure 4 .

Figure 4: Timing in the benchmark model

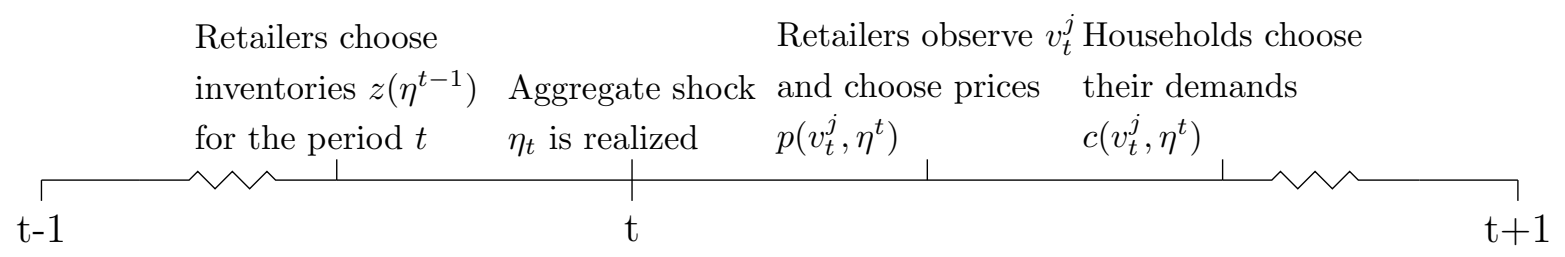


The inventories of imported good are chosen before the aggregate and individual demand shocks are observed, but prices are set after overall uncertainty in the current period is resolved. Later, I will relax this assumption and consider the model with predetermined prices.

\subsection{Households}

A small economy is inhabited by representative household, which maximizes expected life-time utility:

$$
\max _{\left\{c\left(\eta^{t}\right), d\left(\eta^{t}\right), b\left(\eta^{t}\right)\right\}} E_{t} \sum_{s=t}^{\infty} \beta^{s-t} \frac{d\left(\eta^{s}\right)^{1-\sigma}}{1-\sigma}
$$

subject to budget constraint and the law of motion for durable goods:

$$
\begin{aligned}
& p\left(\eta^{t}\right) c\left(\eta^{t}\right)+R^{-1}\left(\tilde{b}\left(\eta^{t}\right)\right) b\left(\eta^{t}\right) \leq b\left(\eta^{t-1}\right)+x\left(\eta^{t}\right)+\pi\left(\eta^{t}\right) \\
& d\left(\eta^{t}\right)=\left(1-\delta_{d}\right) d\left(\eta^{t-1}\right)+\phi\left(\frac{c\left(\eta^{t}\right)}{d\left(\eta^{t-1}\right)}\right) d\left(\eta^{t-1}\right)
\end{aligned}
$$

Here $c\left(\eta^{t}\right)$ denotes purchases of new durable goods, $p\left(\eta^{t}\right)$ is a consumption price index, $b\left(\eta^{t}\right)$ is the holdings of risk-free asset with a gross interest rate $R\left(\tilde{b}\left(\eta^{t}\right)\right), d\left(\eta^{t}\right)$ is a stock of durable goods, $\phi(\cdot)$ is a durable goods adjustment costs function, $\delta_{d}$ denotes a depreciation rate of the durables, $\pi\left(\eta^{t}\right)$ is profits from retailers, $x\left(\eta^{t}\right)$ is an export endowment. ${ }^{7}$

The assumption of incomplete financial markets in the stochastic framework of small open economy results in steady state that depends on initial conditions and equilibrium dynamics that possess a random walk component. To induce stationarity I follow SchmittGrohe and Uribe (2003) and assume that domestic interest rate, $R$, is a decreasing function of the aggregate holdings of foreign assets, $\tilde{b}{ }^{8}$ Specifically, the following functional form is assumed: $R(\tilde{b})=r+\xi(\exp (\bar{b}-\tilde{b})-1)$, where $r$ is a (gross) foreign interest rate and $\bar{b}$ is a deterministic steady-state level of foreign assets.

Aggregate consumption, $c\left(\eta^{t}\right)$, is a CES basket of the retail varieties $c\left(v_{t}, \eta^{t}\right)$ priced at $p\left(v_{t}, \eta^{t}\right)$, where idiosyncratic demand shocks $v_{t}$ are Pareto distributed over $[1, \infty)$ with distribution function $G(v)=1-v^{-a}$ :

$$
c\left(\eta^{t}\right)=\left(\int_{1}^{\infty} v_{t}^{\frac{1}{\theta}} c^{\frac{\theta-1}{\theta}}\left(v_{t}, \eta^{t}\right) d G\left(v_{t}\right)\right)^{\frac{\theta}{\theta-1}}
$$

\footnotetext{
${ }^{7}$ Durable goods adjustment costs function $\phi(\cdot)$ is introduced to reduce the volatility of new purchases of durable goods. This function has to satisfy the following properties in a steady state: $\phi\left(\delta_{d}\right)=\delta_{d}$, $\phi^{\prime}\left(\delta_{d}\right)=1$ and $\phi^{\prime \prime}\left(\delta_{d}\right)=\psi<0$.

${ }^{8}$ Households do not internalize the effects of aggregate assets on the interest rate in their optimal choice of $b$. In the equilibrium, however, aggregate level of foreign assets, $\tilde{b}$, and individual household choice of assets, $b$, will be equalized.
} 
where $\theta>1$ denotes elasticity of substitution across varieties.

Households allocate their consumption by solving expenditure minimization problem taking prices of varieties, $p\left(v_{t}, \eta^{t}\right)$, as given:

$$
c\left(v_{t}, \eta^{t}\right)=v_{t}\left(\frac{p\left(v_{t}, \eta^{t}\right)}{p\left(\eta^{t}\right)}\right)^{-\theta} c\left(\eta^{t}\right)
$$

As a result of this problem, the price of aggregate consumption is given by the following equation:

$$
p\left(\eta^{t}\right)=\left(\int_{1}^{\infty} v_{t} p^{1-\theta}\left(v_{t}, \eta^{t}\right) d G\left(v_{t}\right)\right)^{\frac{1}{1-\theta}}
$$

\subsection{Retailers}

In this small open economy there is a measure one of monopolistically competitive retail firms. Retailers import homogeneous foreign good, repack it into some variety of consumer durable good and sell these varieties to domestic households. When choosing inventory stock for the next period, retailers observe neither aggregate state $\eta_{t}$ nor idiosyncratic shocks $v_{t}^{j}$. However, the firms set their price after overall uncertainty (aggregate and idiosyncratic) in the period $t$ is resolved.

The retail firm $j$ maximizes its expected discounted stream of profits:

$$
\max _{\left\{z\left(j, \eta^{t}\right), p\left(v_{t}^{j}, \eta^{t}\right)\right\}} E_{t} \sum_{s=t}^{\infty} \frac{\beta^{s-t} \lambda\left(\eta^{s}\right)}{\lambda\left(\eta^{t}\right)}\left[p\left(v_{s}^{j}, \eta^{s}\right) y\left(v_{s}^{j}, \eta^{s}\right)-q\left(\eta^{s}\right)\left(z\left(j, \eta^{s}\right)-s\left(v_{s}^{j}, \eta^{s}\right)\right)\right]
$$

subject to:

$$
\begin{aligned}
& y\left(v_{t}^{j}, \eta^{t}\right) \leq z\left(j, \eta^{t-1}\right) \\
& s\left(v_{t}^{j}, \eta^{t}\right)=\left(1-\delta_{s}\right)\left(z\left(j, \eta^{t-1}\right)-y\left(v_{t}^{j}, \eta^{t}\right)\right)
\end{aligned}
$$

where $q\left(\eta^{t}\right)$ is a price of import, $z\left(j, \eta^{t}\right)$ is a desired inventory stock in the next period, $y\left(v_{t}^{j}, \eta^{t}\right)$ denotes retail sales, $\delta_{s}$ is an inventory depreciation rate, $s\left(v_{t}, \eta^{t}\right)$ denotes unsold post-depreciation inventories, $\frac{\beta^{s-t} \lambda\left(\eta^{s}\right)}{\lambda\left(\eta^{t}\right)}$ is a stochastic discount factor. To avoid the problem of keeping cross-firm distribution of inventories it is assumed that unsold inventories can be returned at the end of the period at the import price $q\left(\eta^{t}\right)$ after depreciation costs are incurred.

\subsection{Foreign shocks and export endowment}

I assume that the price of imported durable good, $q\left(\eta^{t}\right)$ and endowment of exported good, $x\left(\eta^{t}\right)$, evolve according to the following $\mathrm{AR}(1)$ processes: 


$$
\begin{aligned}
& \log q\left(\eta^{t}\right)=\left(1-\rho_{q}\right) \log \bar{q}+\rho_{q} \log q\left(\eta^{t-1}\right)+\epsilon_{q}\left(\eta^{t}\right) \\
& \log x\left(\eta^{t}\right)=\left(1-\rho_{x}\right) \log \bar{x}+\rho_{x} \log x\left(\eta^{t-1}\right)+\epsilon_{x}\left(\eta^{t}\right)
\end{aligned}
$$

where $\bar{q}$ and $\bar{x}$ are steady state levels and $\epsilon_{q}\left(\eta^{t}\right)$ and $\epsilon_{x}\left(\eta^{t}\right)$ are respectively shocks to the import price and export.

The (gross) foreign interest rate, $r$, is assumed to be constant (as in Schmitt-Grohe and Uribe, 2003).

\subsection{Equilibrium and its preliminary analysis}

I define an equilibrium of a small open economy and then provide its preliminary analysis.

Definition. An equilibrium in this economy is defined as allocations $\left\{c\left(\eta^{t}\right), c\left(v_{t}^{j}, \eta^{t}\right), d\left(\eta^{t}\right)\right.$, $\left.b\left(\eta^{t}\right), \tilde{b}\left(\eta^{t}\right), \pi\left(\eta^{t}\right), y\left(v_{t}^{j}, \eta^{t}\right), z\left(j, \eta^{t}\right), s\left(v_{t}^{j}, \eta^{t}\right)\right\}_{t=0}^{\infty}$ and prices $\left\{p\left(\eta^{t}\right), p\left(v_{t}^{j}, \eta^{t}\right), R\left(\eta^{t}\right)\right\}_{t=0}^{\infty}$ such that, given the price of imported good, $q\left(\eta^{t}\right)$, foreign interest rate, $r\left(\eta^{t}\right)$, endowment of exported good, $x\left(\eta^{t}\right)$, and initial stocks of $z_{-1}, d_{-1}$ and $b_{-1}$,

(i) the allocations satisfy the household's life-time utility maximization problem and expenditure minimization problem, as well as retailers' profit maximization problems;

(ii) individual holdings of risk-free bond equal its aggregate holdings: $b\left(\eta^{t}\right)=\tilde{b}\left(\eta^{t}\right)$;

(iii) markets clear for all disaggregated retail goods: $c\left(v_{t}^{j}, \eta^{t}\right)=y\left(v_{t}^{j}, \eta^{t}\right)$.

A full set of the equilibrium conditions for this model is given in Appendix A. In this section, I only briefly discuss the main features of this equilibrium. Here and henceforward, to simplify the notation, I drop the dependence on $\eta^{t}$ in the model's allocations and prices.

The household's optimal choice of individual holdings of risk-free bond, $b_{t}$, stock of durables, $d_{t}$, and new purchases of durable goods, $c_{t}$, is given by the following equations:

$$
\begin{aligned}
\lambda_{t} & =R\left(\tilde{b}_{t}\right) \beta E_{t} \lambda_{t+1} \\
\mu_{t} & =d_{t}^{-\sigma}+\beta E_{t} \mu_{t+1}\left(1-\delta_{d}+\phi\left(\frac{c_{t+1}}{d_{t}}\right)-\phi^{\prime}\left(\frac{c_{t+1}}{d_{t}}\right) \frac{c_{t+1}}{d_{t}}\right) \\
p_{t} \lambda_{t} & =\mu_{t} \phi^{\prime}\left(\frac{c_{t}}{d_{t-1}}\right)
\end{aligned}
$$

where $\lambda_{t}$ and $\mu_{t}$ denote marginal utilities (shadow values) of wealth in the form of risk-free bond and durable goods respectively.

It follows from the equation (14) that, if in the next period households expect an increase in retail price, $p_{t+1}$, or in their marginal utility of wealth, $\lambda_{t+1}$, then the next period shadow price of the stock of durables, $\mu_{t+1}$, will increase too. Therefore, equation (13) 
implies that it is optimal to build up a stock of durables today. Intuitively, when people expect that prices of durable goods will be higher tomorrow or their income will fall, it is worth to shift future purchases of new durables for today. ${ }^{9}$ Clearly, this mechanism does not exist for non-durable (and non-storable) goods.

To maximize his profits, the retailer $j$ chooses a desired inventory stock for the next period, $z\left(j, \eta^{t}\right)$, (before observing $\eta_{t+1}$ and $v_{t+1}^{j}$ ) and his optimal retail price $p\left(v_{t}^{j}, \eta^{t}\right)$ (after observing $\eta_{t}$ and $v_{t}^{j}$ ). Given the ex ante symmetry of the problem with respect to inventory choice, all retailers choose the same stock of inventories, $z_{t}$. In contrast, the retailer's optimal price decision depends on threshold value of demand shock $\hat{v}_{t}$ :

$$
p\left(v_{t}, \eta^{t}\right)= \begin{cases}\hat{p}_{t}=\frac{\theta}{\theta-1}\left(1-\delta_{s}\right) q_{t}, & \text { if } v_{t} \leq \hat{v}_{t} \\ \left(\frac{v_{t} c_{t}}{z_{t-1}}\right)^{\frac{1}{\theta}} p_{t}, & \text { if } v_{t}>\hat{v}_{t}\end{cases}
$$

If the retailer's demand shock is low, $v_{t}^{j} \leq \hat{v}_{t}$, so the stock of inventories exceeds current demand, then his optimal price is computed as a constant markup, $\frac{\theta}{\theta-1}$, over marginal shadow costs, $\left(1-\delta_{s}\right) q_{t}$. In other words, this retailer has to be indifferent between selling the marginal unit of inventories in the beginning of the period $t$ or to carry it forward to the end of this period, when he will be able to return this unit at price $q_{t}$ (net of depreciation costs) or to use it to build-up a stock of inventories for the following period. In contrast, the retailer with high idiosyncratic demand shock, $v_{t}^{j}>\hat{v}_{t}$, has no enough inventories to satisfy his current demand at threshold price, $\hat{p}_{t}$, and sells at higher price, $p_{t}^{j}$, that eliminates a shortage: $c_{t}^{j}=v_{t}^{j}\left(\frac{p_{t}^{j}}{p_{t}}\right)^{-\theta} c_{t}=z_{t-1}$.

It is clear, that both branches of the equation (15) are equalized for the retailer with threshold demand shock $\hat{v}_{t}$ :

$$
\hat{v}_{t}\left(\frac{\hat{p}_{t}}{p_{t}}\right)^{-\theta} c_{t}=z_{t-1}
$$

Hence, the prices of stocked-out firms may be expressed as $p_{t}^{j}=\left(\frac{v_{t}^{j}}{\hat{v}_{t}}\right)^{\frac{1}{\theta}} \hat{p}_{t}$. Using equation (6) for the aggregate price index and assuming Pareto distribution of the idiosyncratic demand shocks, as in Alessandria et al. (2013), the following analytical formula for the retail price index can be derived:

$$
p_{t}=\hat{p}_{t}\left[\hat{v}_{t}^{1-a}\left(\frac{a}{1-a}-\frac{a}{\frac{1}{\theta}-a}\right)-\frac{a}{1-a}\right]^{\frac{1}{1-\theta}}
$$

\footnotetext{
${ }^{9}$ Similar logic works in the models with lumpy consumption of durable goods. In particular, Caplin and Leahy (2006) proposed a linearizable (S,s)-model with durable goods that incorporates infrequent purchases. To simplify the equilibrium they assumed that there is a sufficient heterogeneity across agents in the time between purchases, that eliminates the echo effects of previous disturbances to demand. In their model, expected increases in price of durables and/or in marginal utility of wealth induce agents to purchase the durable good earlier.
} 
The retailers' optimal choice of desired inventory stock, $z_{t}$, gives the following equilibrium equation:

$$
\frac{1}{a \theta-1} E_{t}\left\{\frac{\beta \lambda_{t+1}}{\lambda_{t}}\left(1-\delta_{s}\right) q_{t+1} \hat{v}_{t+1}^{-a}\right\}=q_{t}-E_{t}\left\{\frac{\beta \lambda_{t+1}}{\lambda_{t}}\left(1-\delta_{s}\right) q_{t+1}\right\}
$$

Substituting equation (16) into equation (18) and transforming it yields the following formula for desired inventory stock, $z_{t}$ :

$$
\begin{aligned}
z_{t} & =\left(E_{t}\left\{\left(\frac{\hat{p}_{t+1}}{p_{t+1}}\right)^{-a \theta} c_{t+1}^{a}\right\}\right)^{\frac{1}{a}}\left(\frac{1}{a \theta-1}\right)^{\frac{1}{a}} \times \\
& \times\left[\frac{q_{t}}{E_{t}\left\{\frac{\beta \lambda_{t+1}}{\lambda_{t}}\left(1-\delta_{s}\right) q_{t+1}\right\}}-1-\frac{\operatorname{Cov}_{t}\left(\hat{v}_{t+1}^{-a}, \frac{\beta \lambda_{t+1}}{\lambda_{t}}\left(1-\delta_{s}\right) q_{t+1}\right)}{E_{t}\left\{\frac{\beta \lambda_{t+1}}{\lambda_{t}}\left(1-\delta_{s}\right) q_{t+1}\right\}}\right]^{-\frac{1}{a}}
\end{aligned}
$$

Similarly to Alessandria et al. (2013), the desired inventory stock is computed as a product of three terms: i) an (expected) aggregate level of demand, ii) the stock-out avoidance motive, and iii) inventory build-up motive in response to transitory aggregate shocks. The last term indicates that it is optimal to build-up inventories when goods are cheap and interest rates are low. Besides, there is an incentive to keep more precautionary inventories when correlation between import costs, $q_{t+1}$, and threshold demand shock, $\hat{v}_{t+1}$, is negative, that is to self-insure from higher probability of stock-outs (i.e. low $\hat{v}_{t+1}$ ) in the periods when building-up new inventories is costly (i.e. high $q_{t+1}$ ). ${ }^{10}$ The most important difference of this model from Alessandria et al. (2013) is that the retailers react to expected (not actual) aggregate demand, rationalizing backlogged inventories after unexpected negative aggregate demand shocks.

\subsection{Calibration}

The model is calibrated to quarterly data. Most parameters are standard and their values are taken from the literature. The benchmark calibration is summarized in Table 1.

I set the quarterly discount factor $\beta$ equal to 0.99 , which implies an annual steady-state real interest rate of about $4 \%$. The inverse of the intertemporal elasticity of substitution, $\sigma$, is fixed at 2 as in most of the literature. The elasticity of substitution between varieties of durable good, $\theta$, is set to 5 , what corresponds to price markup equal to $25 \%$, i.e. an average level of price markups in retail trade in Russia.

The quarterly depreciation rate of durable goods, $\delta_{d}$, is set to 0.05 , close to the BEA depreciation estimates for some categories of durable goods owned by consumers (video and audio products, trucks, etc.). I choose the parameter of durable goods adjustment cost, $\psi$, to ensure that the standard deviation of non-food goods (which include durables)

\footnotetext{
${ }^{10}$ This effect is of the second order and vanishes in the log-linearised model.
} 
is two times greater than the standard deviation of food consumption, as in Russian data. This value of $\psi$ is equal to 0.3 .

The quarterly inventory depreciation rate, $\delta_{s}$, is set to 0.035 as in Kryvtsov and Midrigan (2013). Given $\delta_{s}$, the parameter $a$ of Pareto distribution for idiosyncratic demand shocks determines the steady-state inventory-sales ratio. I choose $a=1.4$ to reproduce an average stock of inventories equal to monthly sales in the retail sector in Russia.

The deterministic steady-state levels of import price, $\bar{q}$, and export endowment, $\bar{x}$, are normalized to 1 . It is assumed that the steady-state asset holdings, $\bar{b}$, are equal to 0 , and (gross) foreign interest rate, $r$, is set to inverse of discount factor $\beta$. Following Schmitt-Grohe and Uribe (2003), I set an asset elasticity of interest rate, $\xi$, equal to 0.000742 .

Table 1: Calibration of the model

\begin{tabular}{llc}
\hline Parameter & Description & Value \\
\hline$\beta$ & discount factor & 0.99 \\
$\sigma$ & risk aversion & 2 \\
$\theta$ & elasticity of substitution & 5 \\
$\delta_{d}$ & durables depreciation & 0.05 \\
$\delta_{s}$ & inventory depreciation & 0.035 \\
$\psi$ & adjustment costs of durables & 0.3 \\
$\xi$ & interest rate elasticity & 0.000742 \\
$\bar{b}$ & steady state assets & 0 \\
$\bar{x}$ & steady state export endowment & 1 \\
$\bar{q}$ & steady state import price & 1 \\
\hline$\rho_{q}$ & persistence of import price shocks & 0.9 \\
$s t d\left(\epsilon_{q}\right)$ & s.d. of import price shocks & 0.075 \\
$\rho_{x}$ & persistence of export endowment shocks & 0.75 \\
$s t d\left(\epsilon_{x}\right)$ & s.d. of export endowment shocks & 0.03 \\
$a$ & distribution of demand shocks & 1.4 \\
\hline
\end{tabular}

Finally, the parameters of exogenous stochastic processes for import price and export endowment were estimated using quarterly data on terms of trade and volume of export in Russia for the period 2005-2015. The persistence parameters, $\rho_{q}$ and $\rho_{x}$, are set equal to 0.9 and 0.75 respectively, whereas the standard deviations of shocks, $\operatorname{std}\left(\epsilon_{q}\right)$ and $\operatorname{std}\left(\epsilon_{x}\right)$, are equal to 0.075 and 0.03 .

\subsection{Simulation results}

The model was log-linearized and solved using the first-order perturbation methods. Figure 5 reports the impulse responses of key variables in the benchmark model to $7.5 \%$ (one standard deviation) positive shock in import price. The blue solid lines show the dynamics of these variables in the model with durable good $\left(\delta_{d}=0.05\right)$, whereas the red dashed lines correspond to the model with non-durable good $\left(\delta_{d}=1\right)$. Both variants of the model demonstrate very similar impulse responses. The only visible difference is that 
retail sales, inventories and imports of durable goods are more volatile than corresponding variables for non-durables.

An increase in import price has a positive effect on the marginal shadow costs of holding inventories. The retailers that are not faced with stock-outs raise their prices proportionally. An aggregate consumer price index rises too reducing a purchasing power of the households' wealth. As a result, retail sales fall on impact and in the following periods. Given that a desired level of inventories is chosen before realization of import price shock, a falling demand generates a backlog of unsold inventories and less frequent stock-outs (higher threshold demand shock) in the first period of this shock. In the face of higher import costs and lower expected demand, the retailers are forced to adjust downwards their desired level of inventories for the second period. But, taking into account a stock of backlogged inventories, that results in a collapse of new import orders. Besides, given that import price shock is transitory, the retailers expect that import will be cheaper in the second period, so they choose a stock of desired inventories lower than expected aggregate demand. Hence, more retailers will be faced with stock-outs after the first period. In the sequel, import price decreases, whereas consumer prices, retail sales, inventories and import return back to their steady-state levels.

Figure 5: Impulse responses to import price shock: benchmark model
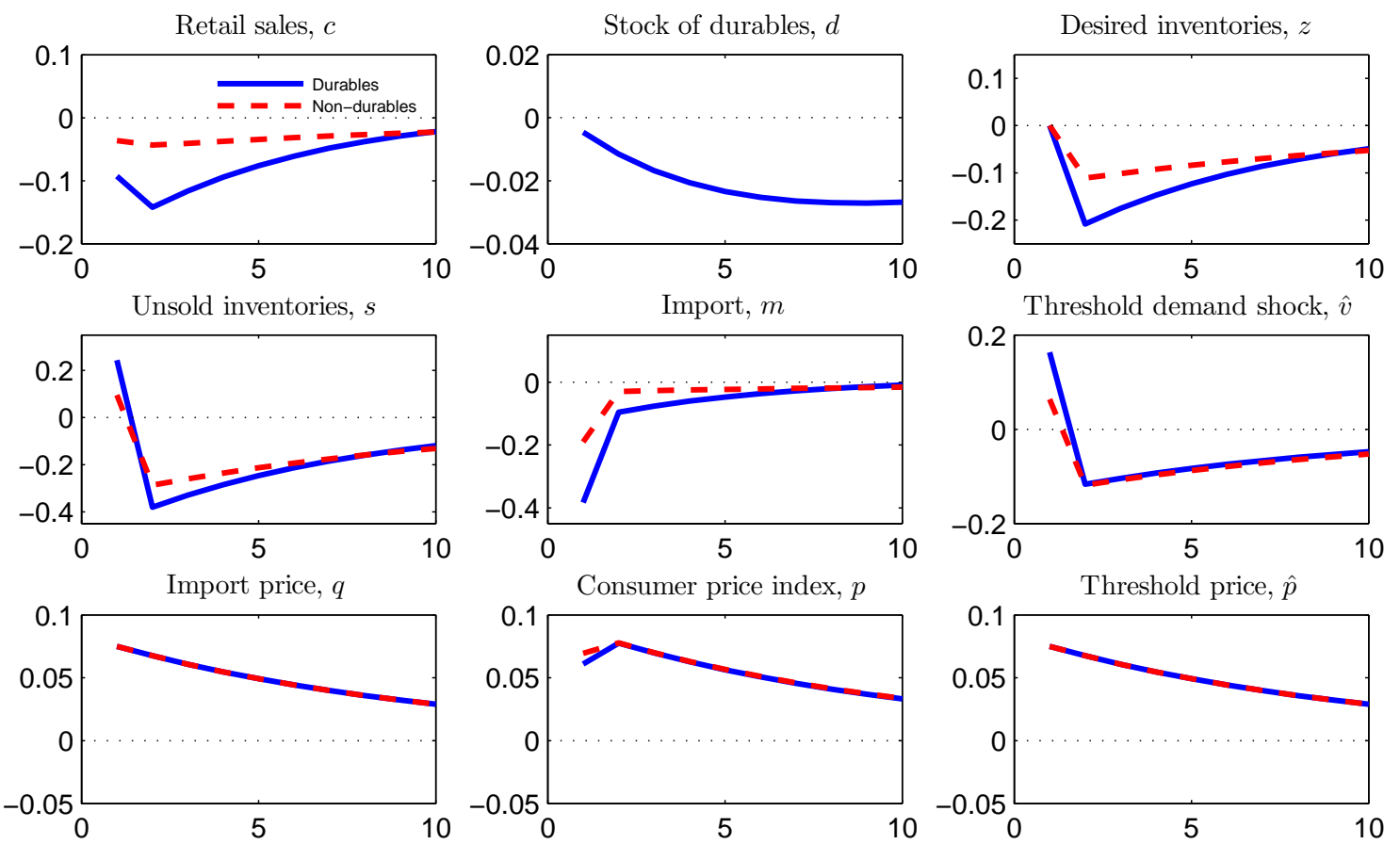

Interestingly, the consumer price index rises gradually in this model. In the first period, stock-outs are less frequent, so the retailers who has been faced with stock-outs and has set relatively high prices before increase their prices less than proportionally to import costs. In contrast, in the second period there are more stock-outs and many recently unconstrained firms become constrained. These retailers increase their prices strongly 
relative to costs, in contrast to unconstrained firms who decrease their prices following a reduction in import price.

However, under reasonable parametrization, this model cannot generate a short-lived spike in retail sales of durable goods immediately after import price shock. To show this, I use equations (16) and (17) to obtain the following relationship between retail sales, desired inventories and threshold demand shock:

$$
c_{t}=\frac{z_{t-1}}{\hat{v}_{t}}\left[\hat{v}_{t}^{1-a}\left(\frac{a}{1-a}-\frac{a}{\frac{1}{\theta}-a}\right)-\frac{a}{1-a}\right]^{\frac{\theta}{\theta-1}}
$$

Given that $z_{t-1}$ is chosen before the period $t$ and $\hat{v}_{t}>1$, it follows that:

$$
\frac{\partial c_{t}}{\partial \hat{v}_{t}}=\frac{z_{t-1}}{\hat{v}_{t}^{2}}\left[\hat{v}_{t}^{1-a}\left(\frac{a}{1-a}-\frac{a}{\frac{1}{\theta}-a}\right)-\frac{a}{1-a}\right]^{\frac{1}{\theta-1}}\left(\frac{a}{a-1}\right)\left(\hat{v}_{t}^{1-a}-1\right)<0
$$

Hence, the retail sales may increase after import price shock only if $\hat{v}_{t}$ decreases. But differentiating equation (17) implies that:

$$
\frac{\partial \hat{p}_{t}}{\partial \hat{v}_{t}}=\left[\hat{v}_{t}^{1-a}\left(\frac{a}{1-a}-\frac{a}{\frac{1}{\theta}-a}\right)-\frac{a}{1-a}\right]^{\frac{\theta}{1-\theta}} \frac{a}{1-a \theta} \hat{v}_{t}^{-a}<0
$$

Hence, an aggregate level of consumer prices should increase more than threshold price when $\hat{v}_{t}$ decreases. But to induce a higher demand on durables in the first period the consumer price level has to rise even more in the second period, despite to decrease in import price. This condition is not consistent with the retailers' and consumers' optimal choices under reasonable parametrization of the model. Intuitively, the retailers adjust prices very quickly to rising import costs and demand, so consumers do not find optimal to increase their consumption.

\section{Model with predetermined prices}

In this section, I modify the benchmark model of a small open economy by assuming that the retailers predetermine their prices for the next period and show that this variant of the model can replicate a short-term increase in retail sales of durable goods after import price shock.

\subsection{Equilibrium with predetermined prices}

Figure 6 illustrates timing in this modified model. In contrast to the benchmark, the retailers set their prices before observing aggregate and idiosyncratic demand shocks, at the same moment when they choose a desired inventory stock for the next period. 
However, this assumption may lead to the situation in which the retailers with high idiosyncratic demand shocks will be faced with shortages in the next period. To avoid rationing, I allow these retailers to reset (increase) their prices to the level, at which they just sell their entire inventory.

Figure 6: Timing in the model with predetermined prices

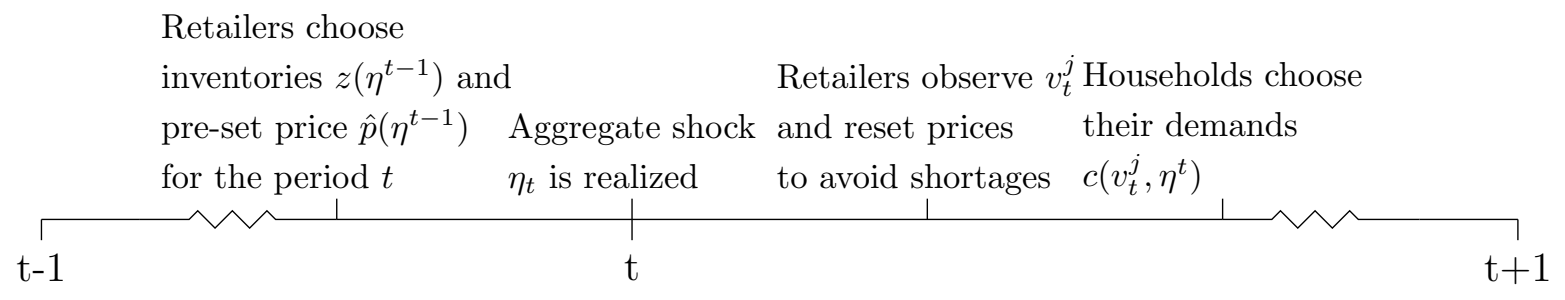

A full set of the equilibrium conditions for modified model is given in Appendix B. Here, I only briefly discuss the main differences of this equilibrium with an equilibrium in the benchmark model. The household's utility maximization problem and expenditure minimization problem remain unchanged, so I concentrate on the retailers' problem only.

The retailers' optimal predetermined price, $\hat{p}_{t}$, for the period $t+1$ is given now by the following formula:

$$
\hat{p}_{t}=\frac{\theta}{\theta-1} \frac{E_{t}\left\{\frac{\beta \lambda_{t+1}}{\lambda_{t}}\left(1-\delta_{s}\right) q_{t+1}\left(\hat{v}_{t+1}^{-1}-\hat{v}_{t+1}^{-a}\right)\right\}}{E_{t}\left\{\frac{\beta \lambda_{t+1}}{\lambda_{t}}\left(\hat{v}_{t+1}^{-1}-\hat{v}_{t+1}^{-a}\right)\right\}}
$$

Given that the model is log-linearized, the only crucial difference of this price from the threshold price in the benchmark model is that it is determined as a markup over expected marginal shadow value of inventories conditional on the information set of the previous period. So, the retailers adjust their prices to import cost shocks with a one-period lag.

A threshold demand shock in this model is determined ex-post, after observing an aggregate state in the period $t$ :

$$
\hat{v}_{t}\left(\frac{\hat{p}_{t-1}}{p_{t}}\right)^{-\theta} c_{t}=z_{t-1}
$$

All retailers with idiosyncratic demand shocks $v_{t}^{j}$ larger than $\hat{v}_{t}$ are allowed to reset their prices to $p_{t}^{j}=\left(\frac{v_{t}^{j}}{\hat{v}_{t}}\right)^{\frac{1}{\theta}} \hat{p}_{t-1}$ to avoid rationing. Thus, the consumption price index is computed as:

$$
p_{t}=\hat{p}_{t-1}\left[\hat{v}_{t}^{1-a}\left(\frac{a}{1-a}-\frac{a}{\frac{1}{\theta}-a}\right)-\frac{a}{1-a}\right]^{\frac{1}{1-\theta}}
$$


Though the threshold price in this modified model reacts to import price shocks with a lag, the aggregate price level, $p_{t}$, may increase immediately. If $\hat{v}_{t}$ rises in response to higher aggregate demand, then more retailers will be faced with stock-outs and will be able to readjust their prices to higher level.

Finally, the retailers' optimal choice of inventories is described by the following equation:

$$
E_{t}\left\{\frac{\beta \lambda_{t+1}}{\lambda_{t}} \hat{v}_{t+1}^{-a}\left(\frac{a(\theta-1)}{a \theta-1} \hat{p}_{t}-\left(1-\delta_{s}\right) q_{t+1}\right)\right\}=q_{t}-E_{t}\left\{\frac{\beta \lambda_{t+1}}{\lambda_{t}}\left(1-\delta_{s}\right) q_{t+1}\right\}
$$

A log-linearization of this equation coupled with a log-linearized optimal price choice (23) yields the same formula as a log-linearized optimal inventory choice in the benchmark model.

Figure 7 reports the impulse responses of key variables in the model with predetermined prices to $7.5 \%$ (one standard deviation) positive shock in import price. As before, the blue solid lines demonstrate the dynamics of these variables in the model with durable good $\left(\delta_{d}=0.05\right)$, whereas the red dashed lines correspond to the model with non-durable $\operatorname{good}\left(\delta_{d}=1\right)$.

Figure 7: Impulse responses to import price shock: the model with predetermined prices
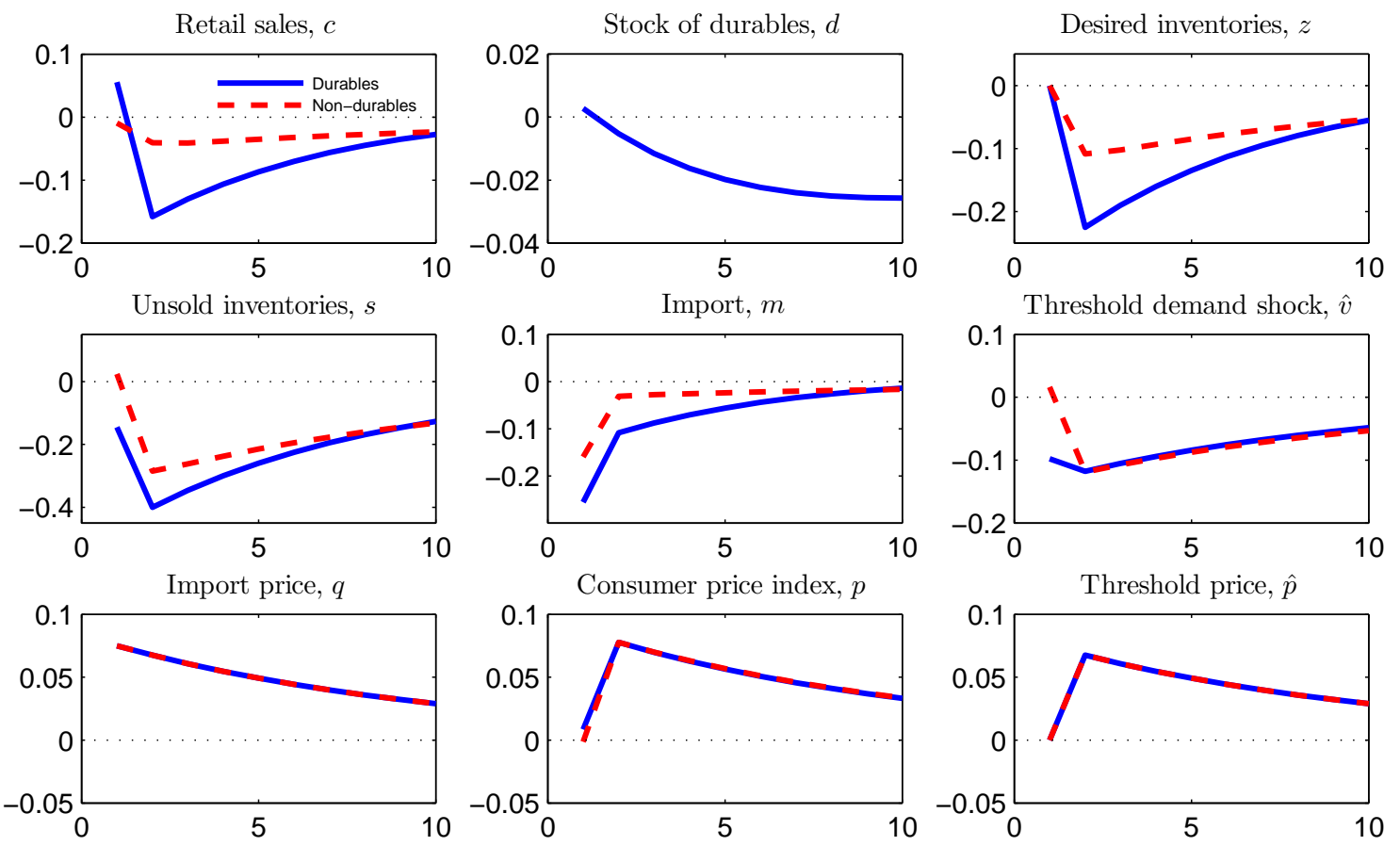

Starting from the second period after the import price shock, the model with predetermined prices demonstrates dynamics similar to the benchmark model: retail sales, inventories and import orders fall, whereas consumer prices increase. However, the modified model behaves very differently in the first period. Since only the retailers who are faced with stock-outs can adjust their prices immediately, an overall price level changes 
only slightly on impact. However, the consumers expect that the retailers will reset their prices upwards in the following period after learning the shock. A higher expected marginal utility of durable goods in the next period implies that it is optimal to increase purchases of durable goods today despite an overall negative effect of import price shock. A spike in retail sales of durables results in decreasing $\hat{v}_{t}$, so more retail firms are faced with stock-outs and start to increase their prices. As a result, consumer price index of durable goods rises slightly in the first period. That is in contrast to the benchmark model, where the retailers adjust quickly to rising import price, the retail sales of durables fall, the level of unsold inventories increases and aggregate price level rises less than proportionally to import costs on impact. Besides, a collapse of import orders is not so bad in the modified model, given that this model does not produce a backlog of unsold inventories of durable goods after the devaluation shock.

Clearly, the modified model does not produce a similar spike in the retail sales of nondurable (and non-storable) goods. Intuitively, it is not possible to shift future purchases of non-storable goods to today when prices are lower and use these goods in the next period. Besides, in contrast to durable goods, the consumer price level of non-durable goods start to rise only in the second period after the shock. These results of the model are fully consistent with the stylized facts about dynamics of retail sales and prices of durable and non-durable goods in Russia after devaluation shock in December, 2014.

\subsection{Model simulations and devaluation in December, 2014}

The simulations can be used to evaluate an ability of the modified model with predetermined prices to account for the actual dynamics of retail sales, inventories, imports and retail prices of durable goods after devaluation of Russian rouble in December, 2014. To do that, I generate 10000 time-series observations of these variables from the model and use the simulated data to construct five-quarter event windows centered on large devaluation event. A large devaluation event is identified as a situation when import price shock, $\epsilon_{q}\left(\eta^{t}\right)$, exceeds its one standard deviation.

Figure 8 shows these event windows for the year-over-year growth rates of retail sales, inventories, imports and prices of durable goods. Each window includes the mean across large devaluation events identified in the 10000 period simulations of the benchmark (blue dash-dot lines) and modified (red dashed lines) models. Figure 8 also includes the actual year-over-year growth rates of retail sales, inventories, imports and prices of cars (which are taken as representatives of durable goods) in Russia around devaluation in December, 2014 .

Figure 8 shows that the model with predetermined prices replicates most of the key features of large devaluation episode in December, 2014. This model predicts a temporary spike in retail sales of cars during the initial phase of this devaluation which is followed 
by more than 20 percent decline. It explains the decrease in inventories and imports and a gradual increase in retail prices of cars. This model matches closely the magnitude of changes in retail sales and retail prices (after correction for pre-crisis inflation), but slightly overestimate the decline in inventories in the first two periods and the decline in imports in the second period after devaluation.

Figure 8: Devaluation event window in data and model simulations
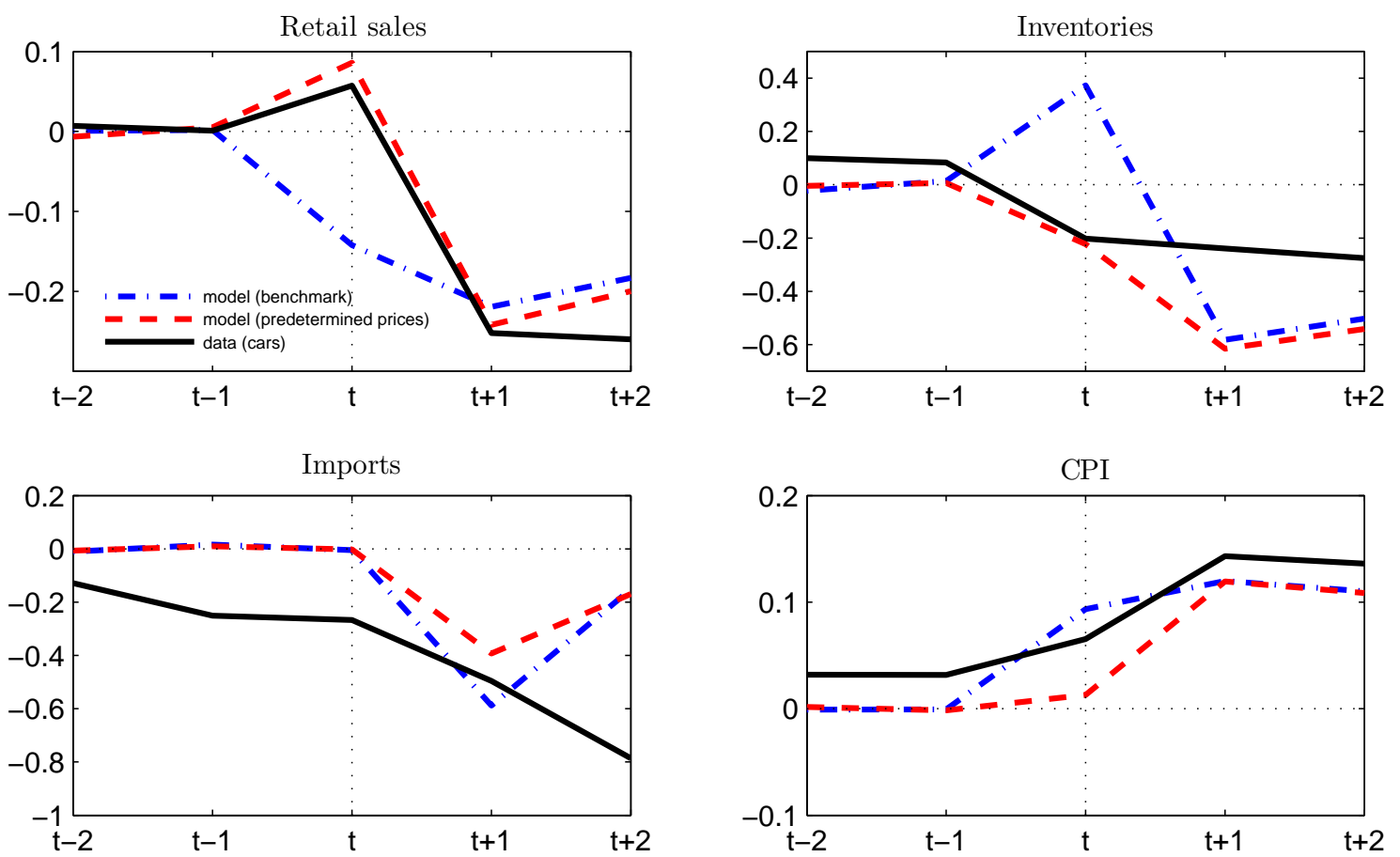

Figure 8 demonstrates also that the (benchmark) model with flexible prices fails to explain the actual behaviour of retail sales and inventories of cars in the period of devaluation in December, 2014. It predicts an immediate decline in retail sales and an increase in unsold inventories. Besides, it overestimate a retail price inflation immediately after devaluation shock.

\section{Sensitivity analysis}

In this section I check sensitivity of the main results of the model. First, I consider the model with alternative timing of inventory decisions. Following Alessandria et al. (2013) and Kryvtsov and Midrigan (2013), I assume that the retailers choose their desired stock of inventories after realization of aggregate import price shock but before learning their idiosyncratic demand shocks, whereas prices are set after all uncertainty in the current period is realized. ${ }^{11}$ Figure 9 reports the impulse response functions of this model

\footnotetext{
${ }^{11}$ The model, where prices are determined after the aggregate shock is observed but before idiosyncratic uncertainty is resolved and the retailers are allowed to reset their prices to avoid shortages, provides similar results.
} 
with durable goods together with IRFs of the benchmark model and the model with predetermined prices.

Figure 9: Impulse responses to import price shock: the model without inventory backlog
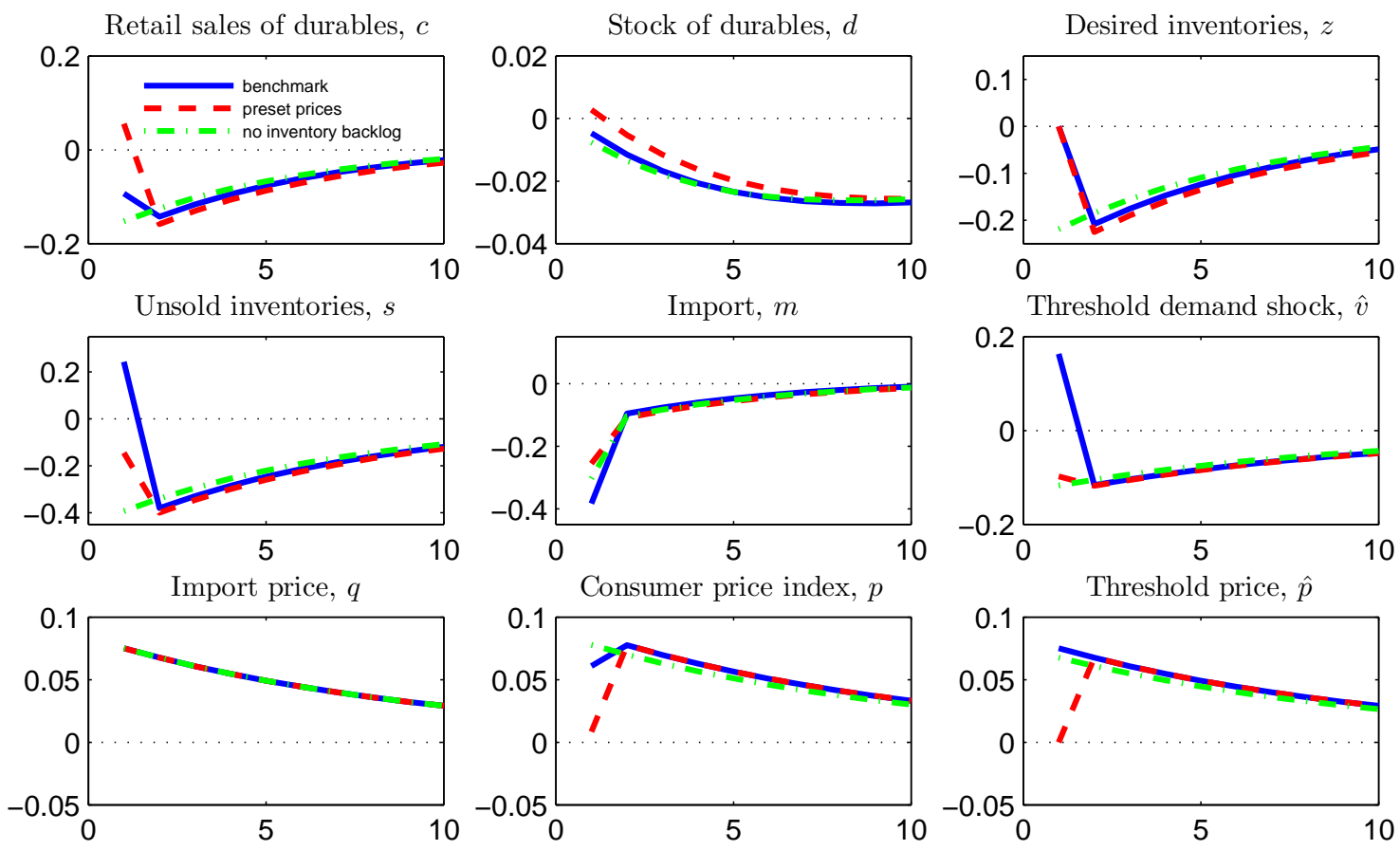

It is clear from this figure that the main difference of this modified variant of the model from the benchmark is that the retailers quickly adjust their desired inventory stocks of durables to import price shocks. As a result, this model does not generate a backlog of inventories, more (not less) retailers will be faced with stock-outs and decide to increase their prices more than proportionally to import costs, so the price level change occurs abruptly, not gradually as in the benchmark model.

Second, Appendix C reports sensitivity of IRFs to different parametrization of the model. In particular, I consider the model with different values of uncertainty of idiosyncratic shocks, $a$, elasticity of substitution between retail varieties, $\theta$, inventory storage costs, $\delta_{s}$, and depreciation of durable goods, $\delta_{d}$. Both the benchmark model and the model with predetermined prices are robust to alternative values of these parameters. The only important observation is that the inventory stock becomes more volatile with larger $a$ (lower idiosyncratic uncertainty), larger $\theta$ (higher substitutability of the varieties) and larger $\delta_{s}$ (larger storage costs). These changes in the parameters of the model are associated with a lower steady-state inventories-to-sales ratio, making inventories more sensitive to import price shocks. Finally, the last figure in Appendix C reconfirms one of the main results of this paper, that, after large devaluations, a short-term spike in retail sales may be observed only for durable goods, but not for non-durables, i.e. the goods with very high depreciation rate $\delta_{d}$. 


\section{Conclusions}

In this paper, I propose a general equilibrium model of a small open economy with imported durable goods, monopolistically competitive retailers and inventory management and show that quantitative predictions of this model are in line with the stylized facts regarding the effects of large devaluation episodes in Russia on the retail sales, inventories, imports and consumer prices of durable goods.

I consider two versions of this model. In the first one, the retailers choose their inventory stocks before observing aggregate and idiosyncratic demand shocks, but set prices after uncertainty in the current period is resolved. Similarly to Alessandria et al. (2010), this model generates a fall of imports, retail sales and inventories, and a gradual rise of consumer prices. However, it fails to explain a short-lived spike in retail sales of durable goods in Russia after collapse of rouble in December, 2014.

To solve this problem, in the second variant of the model, I assume that retail prices are pre-set before the retailers observe aggregate and idiosyncratic shocks. To avoid rationing by the firms, who experience stock-outs of inventories in the next period, I allow these retailers to reset their prices to the level eliminating shortages. This modified model with predetermined prices succeeds to generate a short-term spike in the retail sales of durable goods after import price shock. 


\section{References}

Aguirregabiria, V. (1999): "The Dynamics of Markups and Inventories in Retailing Firms," The Review of Economic Studies, 66, 275-308.

Alessandria, G., J. Kaboski, and V. Midrigan (2013): "Trade Wedges, Inventories, and International Business Cycles," Journal of Monetary Economics, 60, 1-20.

Alessandria, G., J. P. Kaboski, and V. Midrigan (2010): "Inventories, Lumpy Trade, and Large Devaluations," American Economic Review, 100, 2304-39.

Blinder, A. S., M. C. Lovell, And L. H. Summers (1981): "Retail Inventory Behavior and Business Fluctuations," Brookings Papers on Economic Activity, 1981, 443-520.

Burstein, A., M. Eichenbaum, And S. Rebelo (2005): "Large Devaluations and the Real Exchange Rate," Journal of Political Economy, 113, 742-784.

Caplin, A. And J. Leahy (2006): "Equilibrium in a durable goods market with lumpy adjustment," Journal of Economic Theory, 128, 187-213.

Cashin, P., L. F. Cespedes, and R. Sahay (2004): "Commodity Currencies and the Real Exchange Rate," Journal of Development Economics, 75, 239-268.

Chen, Y. And K. Rogoff (2003): "Commodity Currencies," Journal of International Economics, 60, 133-160.

Gopinath, G., O. Itskhomi, and R. Rigobon (2010): "Currency Choice and Exchange Rate Pass-Through," American Economic Review, 100, 304-36.

Kahn, J. A. (1987): "Inventories and the Volatility of Production," The American Economic Review, 77, 667-679.

Kryvtsov, O. And V. Midrigan (2013): "Inventories, Markups, and Real Rigidities in Menu Cost Models," Review of Economic Studies, 80, 249-276.

MendozA, E. (1991): "Real Business Cycles in a Small Open Economy," The American Economic Review, 81, 797-818.

SCARF, H. E. (1960): "The optimality of (S, s) policies in the dynamic inventory problem," Mathematical Methods in the Social Sciences, 196-202.

Schmitt-Grohe, S. And M. Uribe (2003): "Closing small open economy models," Journal of International Economics, 61, 163-185.

WEN, Y. (2005): "Understanding the inventory cycle," Journal of Monetary Economics, 52, 1533-1555. 


\section{Appendices}

\section{A Equilibrium in the benchmark model}

In this appendix we discuss an equilibrium of the benchmark model of a small commodity-exporting economy.

The representative household's optimal choice of the holdings of risk-free asset:

$$
\lambda_{t}=R\left(b_{t}\right) \beta E_{t} \lambda_{t+1}
$$

Gross risk-free interest rate:

$$
R\left(b_{t}\right)=r+\xi\left(\exp \left(\bar{b}-b_{t}\right)-1\right)
$$

The representative household's optimal choice of the durables stock:

$$
\mu_{t}=d_{t}^{-\sigma}+\beta E_{t} \mu_{t+1}\left(1-\delta_{d}+\phi\left(\frac{c_{t+1}}{d_{t}}\right)-\phi^{\prime}\left(\frac{c_{t+1}}{d_{t}}\right) \frac{c_{t+1}}{d_{t}}\right)
$$

The representative household's optimal choice of the new durable goods' consumption:

$$
p_{t} \lambda_{t}=\mu_{t} \phi^{\prime}\left(\frac{c_{t}}{d_{t-1}}\right)
$$

The law of motion of durables:

$$
d_{t}=\left(1-\delta_{d}\right) d_{t-1}+\phi\left(\frac{c_{t}}{d_{t-1}}\right) d_{t-1}
$$

The retailers' optimal threshold price:

$$
\hat{p}_{t}=\frac{\theta}{\theta-1}\left(1-\delta_{s}\right) q_{t}
$$

Threshold demand shock:

$$
\hat{v}_{t}\left(\frac{\hat{p}_{t}}{p_{t}}\right)^{-\theta} c_{t}=z_{t-1}
$$

Consumption price index:

$$
p_{t}=\hat{p}_{t}\left[\hat{v}_{t}^{1-a}\left(\frac{a}{1-a}-\frac{a}{\frac{1}{\theta}-a}\right)-\frac{a}{1-a}\right]^{\frac{1}{1-\theta}}
$$

The retailers' optimal choice of inventories:

$$
\frac{1}{a \theta-1} E_{t}\left\{\frac{\beta \lambda_{t+1}}{\lambda_{t}}\left(1-\delta_{s}\right) q_{t+1} \hat{v}_{t+1}^{-a}\right\}=q_{t}-E_{t}\left\{\frac{\beta \lambda_{t+1}}{\lambda_{t}}\left(1-\delta_{s}\right) q_{t+1}\right\}
$$

Unsold inventories:

$$
s_{t}=\left(1-\delta_{s}\right)\left(z_{t-1}-\frac{z_{t-1}}{\hat{v}_{t}}\left(\frac{\hat{v}_{t}^{1-a}}{1-a}-\frac{a}{1-a}\right)\right)
$$


New import orders:

$$
m_{t}=z_{t}-s_{t}
$$

Balance of payments:

$$
x_{t}-q_{t} m_{t}=R^{-1}\left(b_{t}\right) b_{t}-b_{t-1}
$$

Import price and export endowment shocks:

$$
\begin{aligned}
\log q_{t} & =\left(1-\rho_{q}\right) \log \bar{q}+\rho_{q} \log q_{t-1}+\epsilon_{q, t} \\
\log x_{t} & =\left(1-\rho_{x}\right) \log \bar{x}+\rho_{x} \log x_{t-1}+\epsilon_{x, t}
\end{aligned}
$$




\section{B Equilibrium in the model with predetermined prices}

In this appendix we discuss an equilibrium of the model of a small commodity-exporting economy with predetermined prices.

The representative household's optimal choice of the holdings of risk-free asset:

$$
\lambda_{t}=R\left(b_{t}\right) \beta E_{t} \lambda_{t+1}
$$

Gross risk-free interest rate:

$$
R\left(b_{t}\right)=r+\xi\left(\exp \left(\bar{b}-b_{t}\right)-1\right)
$$

The representative household's optimal choice of the durables stock:

$$
\mu_{t}=d_{t}^{-\sigma}+\beta E_{t} \mu_{t+1}\left(1-\delta_{d}+\phi\left(\frac{c_{t+1}}{d_{t}}\right)-\phi^{\prime}\left(\frac{c_{t+1}}{d_{t}}\right) \frac{c_{t+1}}{d_{t}}\right)
$$

The representative household's optimal choice of the new durable goods' consumption:

$$
p_{t} \lambda_{t}=\mu_{t} \phi^{\prime}\left(\frac{c_{t}}{d_{t-1}}\right)
$$

The law of motion of durables:

$$
d_{t}=\left(1-\delta_{d}\right) d_{t-1}+\phi\left(\frac{c_{t}}{d_{t-1}}\right) d_{t-1}
$$

The retailers' optimal threshold price:

$$
\hat{p}_{t}=\frac{\theta}{\theta-1} \frac{E_{t}\left\{\frac{\beta \lambda_{t+1}}{\lambda_{t}}\left(1-\delta_{s}\right) q_{t+1}\left(\hat{v}_{t+1}^{-1}-\hat{v}_{t+1}^{-a}\right)\right\}}{E_{t}\left\{\frac{\beta \lambda_{t+1}}{\lambda_{t}}\left(\hat{v}_{t+1}^{-1}-\hat{v}_{t+1}^{-a}\right)\right\}}
$$

Threshold demand shock:

$$
\hat{v}_{t}\left(\frac{\hat{p}_{t-1}}{p_{t}}\right)^{-\theta} c_{t}=z_{t-1}
$$

Consumption price index:

$$
p_{t}=\hat{p}_{t-1}\left[\hat{v}_{t}^{1-a}\left(\frac{a}{1-a}-\frac{a}{\frac{1}{\theta}-a}\right)-\frac{a}{1-a}\right]^{\frac{1}{1-\theta}}
$$

The retailers' optimal choice of inventories:

$$
E_{t}\left\{\frac{\beta \lambda_{t+1}}{\lambda_{t}} \hat{v}_{t+1}^{-a}\left(\frac{a(\theta-1)}{a \theta-1} \hat{p}_{t}-\left(1-\delta_{s}\right) q_{t+1}\right)\right\}=q_{t}-E_{t}\left\{\frac{\beta \lambda_{t+1}}{\lambda_{t}}\left(1-\delta_{s}\right) q_{t+1}\right\}
$$

Unsold inventories:

$$
s_{t}=\left(1-\delta_{s}\right)\left(z_{t-1}-\frac{z_{t-1}}{\hat{v}_{t}}\left(\frac{\hat{v}_{t}^{1-a}}{1-a}-\frac{a}{1-a}\right)\right)
$$

New import orders:

$$
m_{t}=z_{t}-s_{t}
$$


Balance of payments:

$$
x_{t}-q_{t} m_{t}=R^{-1}\left(b_{t}\right) b_{t}-b_{t-1}
$$

Import price and export endowment shocks:

$$
\begin{aligned}
\log q_{t} & =\left(1-\rho_{q}\right) \log \bar{q}+\rho_{q} \log q_{t-1}+\epsilon_{q, t} \\
\log x_{t} & =\left(1-\rho_{x}\right) \log \bar{x}+\rho_{x} \log x_{t-1}+\epsilon_{x, t}
\end{aligned}
$$




\section{Sensitivity analysis}

Figure 10: Sensitivity to idiosyncratic uncertainty, $a$
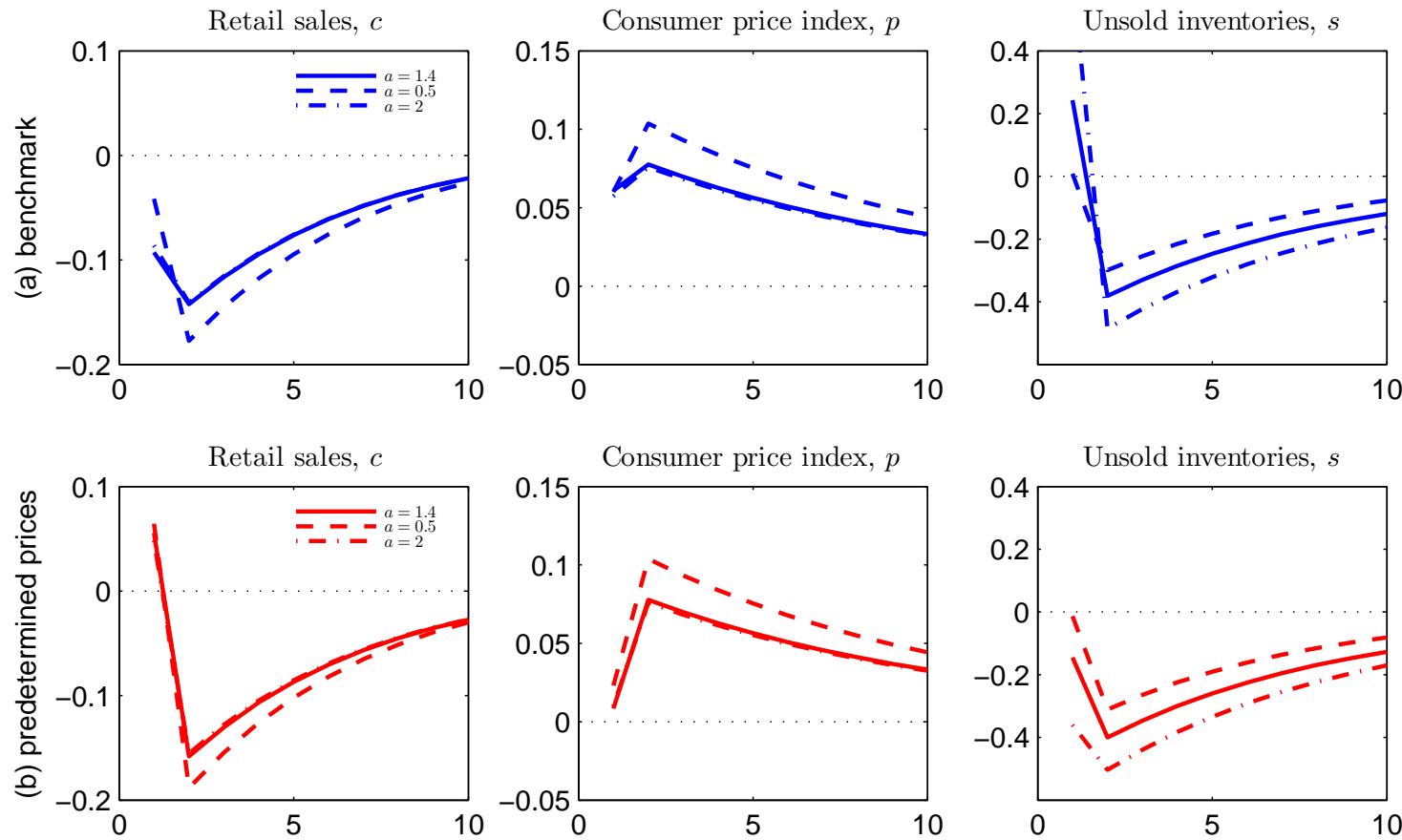

Figure 11: Sensitivity to elasticity of substitution across varieties, $\theta$
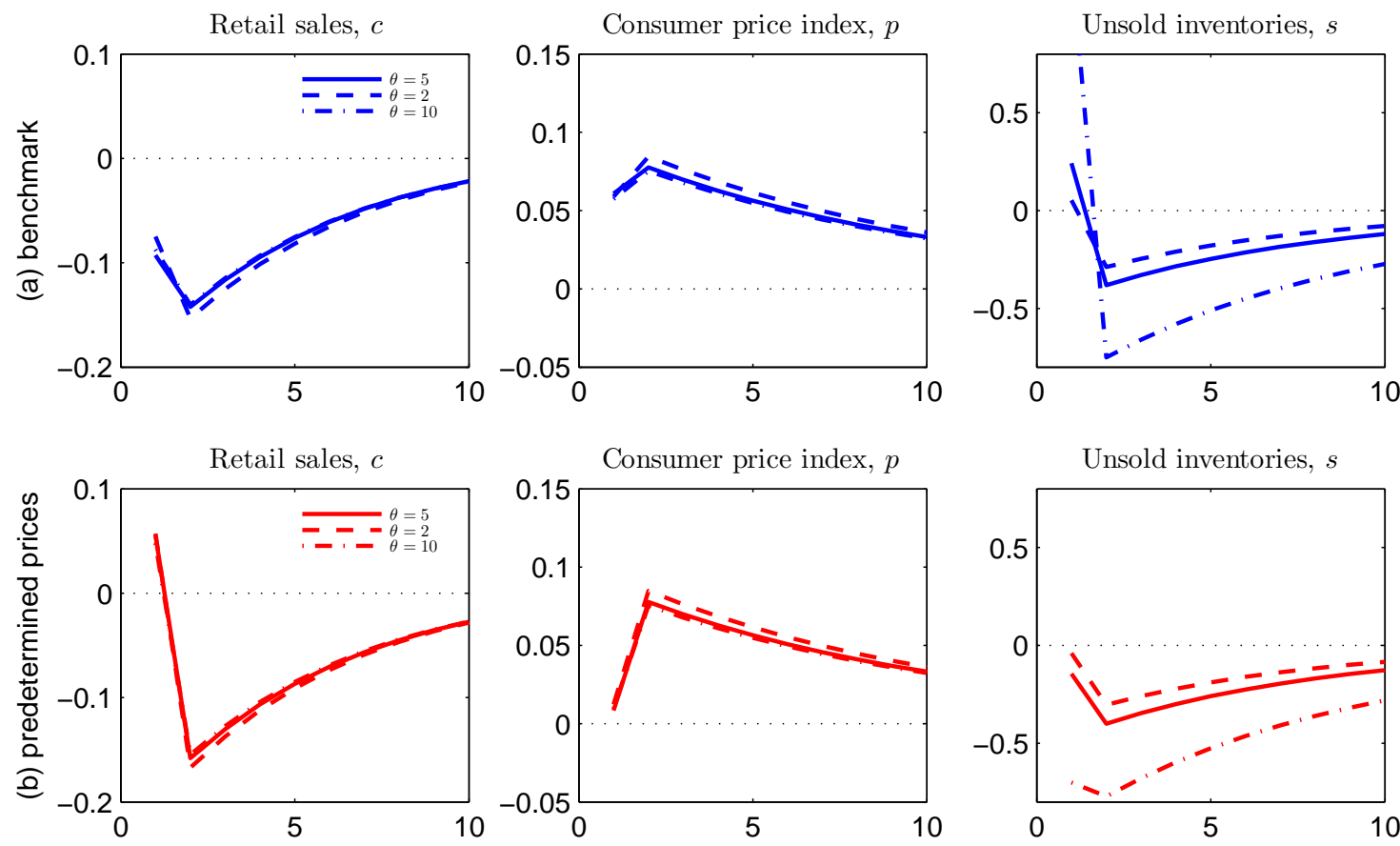
Figure 12: Sensitivity to inventory storage costs, $\delta_{s}$
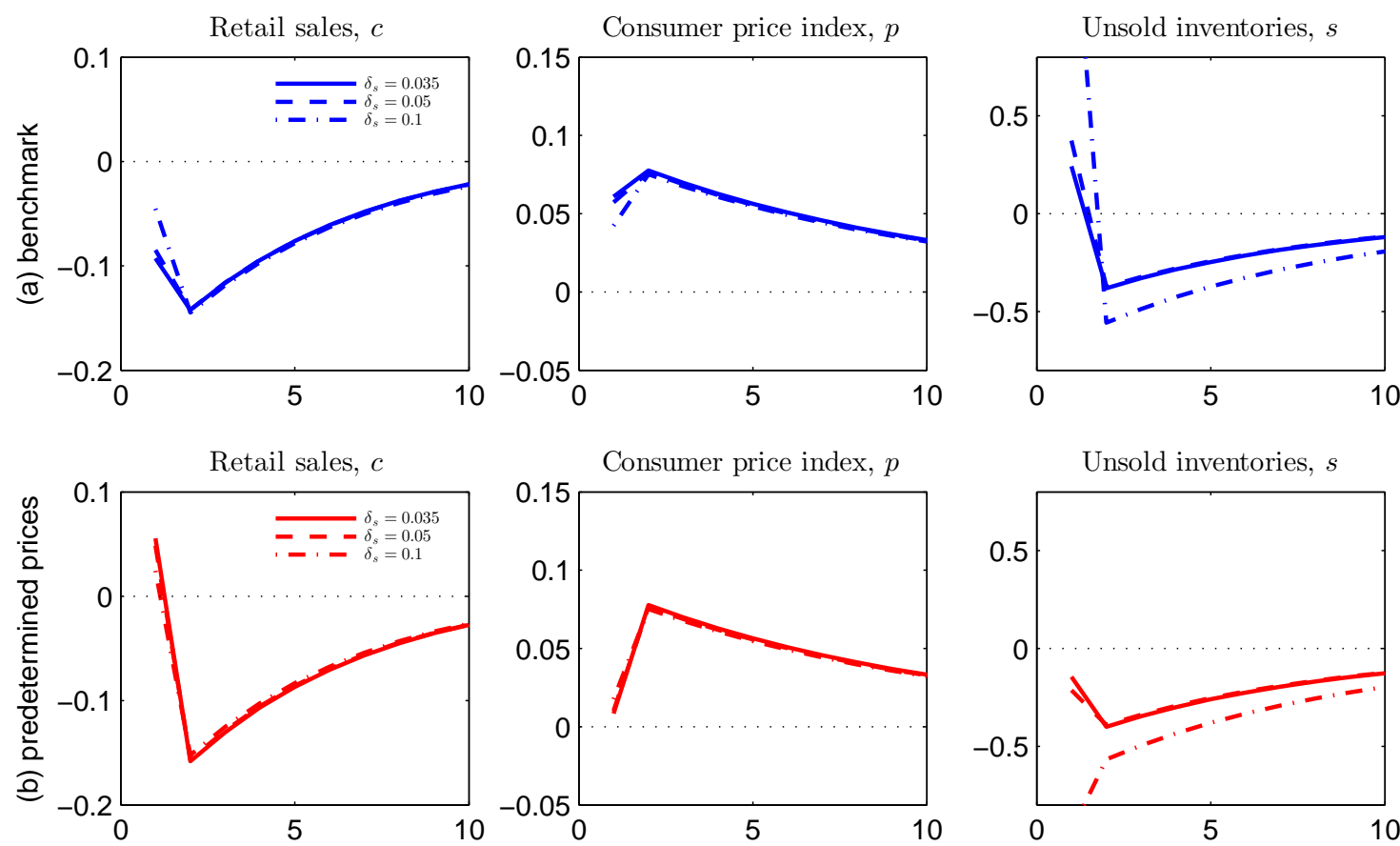

Figure 13: Sensitivity to depreciation rate of durables, $\delta_{d}$
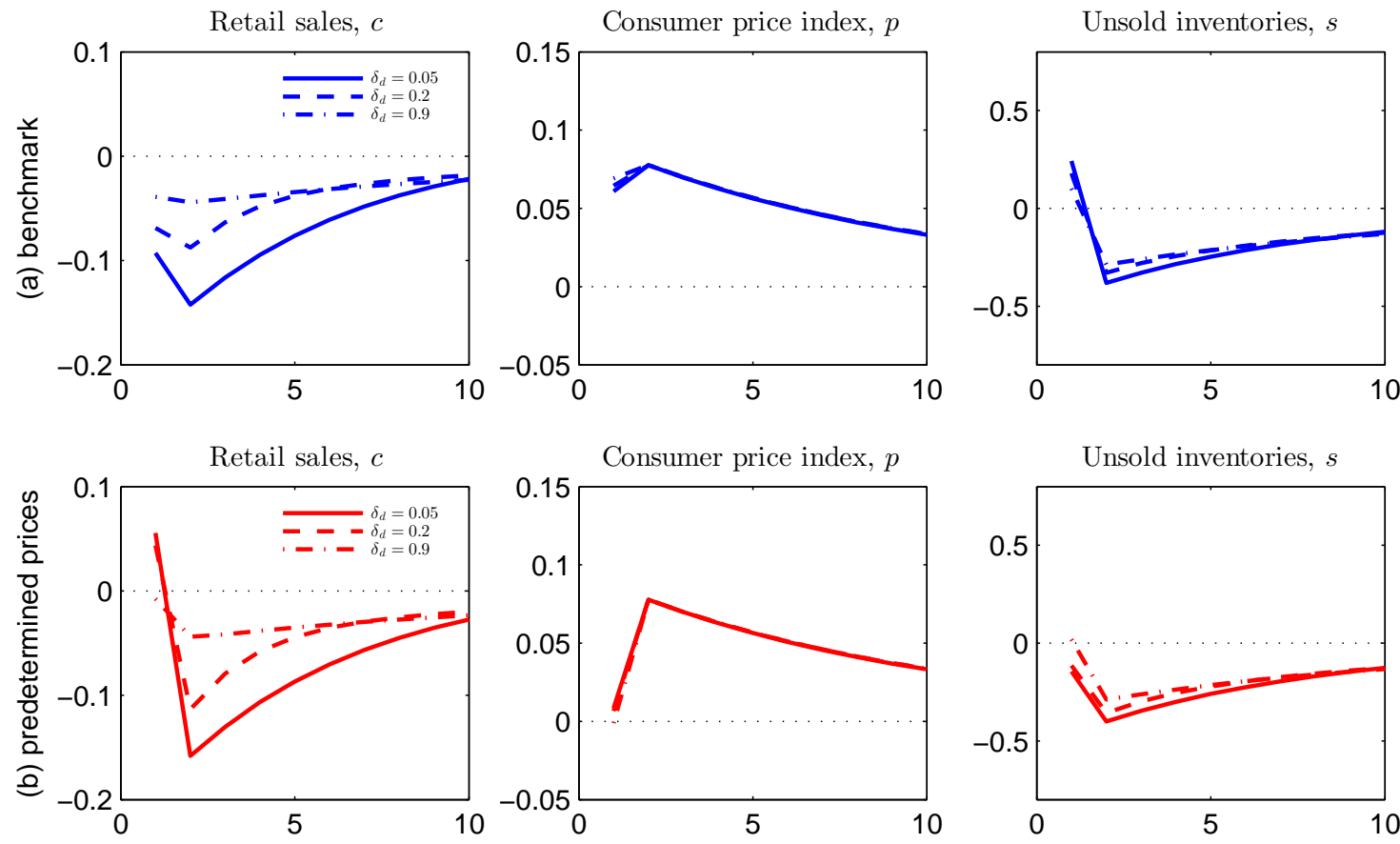